\title{
Determination of land surface reflectance using the AATSR dual-view capability
}

\author{
L. Sogacheva ${ }^{1}$, P. Kolmonen ${ }^{1}$, T. H. Virtanen ${ }^{1}$, E. Rodriguez ${ }^{1}$, A.-M. Sundström ${ }^{2}$, and G. de Leeuw ${ }^{1,2}$ \\ ${ }^{1}$ Finnish Meteorological Institute, Helsinki, Finland \\ ${ }^{2}$ Department of Physics, University of Helsinki, Helsinki, Finland \\ Correspondence to: L. Sogacheva (larisa.sogacheva@fmi.fi)
}

Received: 9 June 2014 - Published in Atmos. Meas. Tech. Discuss.: 23 July 2014

Revised: 19 December 2014 - Accepted: 23 December 2014 - Published: 22 February 2015

\begin{abstract}
In this study, a method is presented to retrieve the surface reflectance using the radiances measured at the top of the atmosphere for the two views provided by the Advanced Along-Track Scanning Radiometer (AATSR). In the first step, the aerosol optical depth (AOD) is obtained using the AATSR dual-view algorithm (ADV) by eliminating the effect of the surface on the measured radiances. Hence the AOD is independent of surface properties and can thus be used in the second step to provide the aerosol part of the atmospheric correction which is needed for the surface reflectance retrieval. The method is applied to provide monthly maps of both AOD and surface reflectance at two wavelengths $(555$ and $659 \mathrm{~nm})$ for the whole year of 2007 .

The results are validated versus surface reflectance provided by the AERONET-based Surface Reflectance Validation Network (ASRVN). Correlation coefficients are 0.8 and 0.9 for 555 and $659 \mathrm{~nm}$, respectively. The standard deviation is 0.001 for both wavelengths and the absolute error is less than 0.02. Pixel-by-pixel comparison with MODIS (Moderate Resolution Imaging Spectrometer) monthly averaged surface reflectances show a good correlation $(0.91$ and 0.89 for 555 and $659 \mathrm{~nm}$, respectively) with somewhat higher values (up to 0.05 ) obtained by ADV over bright surfaces. The difference between the ADV- and MODIS-retrieved surface reflectances is smaller than \pm 0.025 for $68.3 \%$ of the collocated pixels at $555 \mathrm{~nm}$ and $79.9 \%$ of the collocated pixels at $659 \mathrm{~nm}$. An application of the results over Australia illustrates the variation in the surface reflectances for different land cover types.

The validation and comparison results suggest that the algorithm can be successfully used for both the AATSR and ATSR-2 (which has characteristics similar to AATSR) mis-
\end{abstract}

sions, which together cover a 17-year period of measurements (1995-2012), as well as a prototype for the Sea and Land Surface Temperature Radiometer (SLSTR) planned to be launched in the fall of 2015 onboard the Sentinel-3 satellite.

\section{Introduction}

The interest in global satellite observations of land properties for application in Earth system science and global climate research is growing (National Research Council, 2004). Surface albedo, defined as the ratio of upwelling to downwelling radiative flux at the surface (Lucht et al., 2000), is one of the most important variables controlling the surface radiation budget. It has been well recognized that the surface albedo is among the main radiative uncertainties in climate modeling (e.g., Hahmann and Dickinson, 2001; Wang et al., 2007). Snow-free albedo is especially important for land surface models that compute the exchange of energy, water, or carbon for various land use categories (Tasumi et al., 2008; Rechid et al., 2009). Land surface albedo is a key input parameter for land cover classification and is also important for remote sensing of clouds (e.g., Taylor and Stowe, 1984; Coddington et al., 2013; Fricke et al., 2014), aerosols (e.g., Kokhanovsky and de Leeuw, 2009; Seidel et al., 2012) and trace gases (e.g., Wagner et al., 2007).

Surface albedo varies spatially and temporally as a result of both natural processes (e.g., vegetation growth, change in soil moisture content, snow aging) and human activity (e.g., deforestation, agriculture, burning). Important factors are the seasonal phenological stage and precipitation. Fur- 
thermore, the orientation of the surface is important: reflectance might increase for non-horizontal surfaces, such as mountain slopes and high vegetation (e.g., Turner et al., 2008). Three-dimensional surface structure (e.g., segmental high vegetation areas, urban areas) causes shadowing, which is a part of the bidirectional reflectance distribution function (BRDF) effect (van Ginneken et al., 1998; Sailor and Fan, 2002).

The determination of land surface albedo is not straightforward. One option is to assign surface albedo to individual surface and vegetation types and combine these with information on land cover to determine the spatial and temporal distribution of the surface albedo. Alternatively, direct measurements can be done at local sites or information can be retrieved from airborne or satellite data. Each of these methods requires a correction for the effect of atmospheric constituents on the measured reflectance (e.g., Manninen et al., 2012). Another complication is that none of these methods measure albedo but surface reflectance for certain geometries and wavelengths, i.e., the fraction of the incoming solar radiation scattered in a certain direction. Obtaining the albedo requires the integration of reflectance over all sun-view geometries.

In this paper we consider the determination of the surface reflectance using satellite-based radiometer measurements. The reflectance measured with a radiometer at the top of the atmosphere (TOA) consists of solar radiation scattered by both the surface and the atmosphere. Hence, retaining either the atmospheric or the surface contribution to the TOA reflectance requires effective decoupling of these two contributions. Traditional methods for estimating the surface shortwave albedo from satellite data include three steps (Tao, 2012): (1) the satellite observations are converted to surface directional reflectance using atmospheric correction algorithms, (2) surface BRDF models are inverted through the fitting of the surface reflectance composites, (3) the shortwave albedo is calculated from the BRDF through angular and spectral integration. Integrals of BRDF functions result in the so-called black-sky (reflection of direct radiation) and white-sky (reflection of diffuse radiation) albedos that convey important information concerning the inherent properties of surface albedo (Wanner et al., 1997).

During the past several decades, remotely sensed surface albedo and reflectance products have been generated using satellite data. The advantage of the use of satellites as opposed to ground-based or airborne measurements is that satellites can provide global coverage during an extended period of time (decades using the currently available spaceborne instruments). Albedo and reflectance anisotropy products (as given by, for example, BRDF), with temporal frequencies varying from daily to monthly and with spatial resolutions varying from $250 \mathrm{~m}$ to $20 \mathrm{~km}$, are derived from sensors on polar-orbiting satellites such as MODIS (Schaaf et al., 2002; Strahler and Muller, 1999), MISR (Lyapustin et al., 2006; Martonchik et al., 1998), POLDER (Bacour and
Brèon, 2005; Hautecoeur et al., 2007), MERIS (Guanter et al., 2008), AATSR (Grey and North, 2009; Sayer et al., 2010) and CERES (Rivkin et al., 2006). An overview of the satellites and methods to retrieve global albedo is presented in Schaaf et al. (2008, 2011). However, disagreements exist between albedo products from different satellite sensors, due to differences in sensors and observation conditions, and in some cases opposing regional and global long-term trends have been reported (Li, 1996; Zhou et al., 2010; Sayer et al., 2012).

To enable the comparison of the surface reflectance retrieved with different satellites, the BRDF has been introduced as a MODIS product (Schaaf et al., 2002). According to Ju et al. (2010), in order to estimate the BRDF, the operational MODIS albedo and anisotropy algorithm makes use of a kernel-driven, linear model of the bidirectional reflectance factors, which relies on the weighted sum of an isotropic parameter and two functions (or kernels) of viewing and illumination geometry. Radiative transfer models can be used to derive one kernel; the other one is based on surface scattering and geometric casting theory. The kernel weights selected are those that best fit the cloud-cleared, atmospherically corrected surface reflectance available for each location globally over a 16-day period (Lucht et al., 2000). Similar kernel-driven schemes are used to obtain BRDF and albedo information from POLDER (Leroy et al., 1997). The MODIS BRDF product is used in the present work for intercomparison of the AATSR-retrieved surface reflectance.

AATSR and its predecessor ATSR-2 provide two views near nadir and $55^{\circ}$ forward - whose capabilities are used in this paper to determine the land surface reflectance. North et al. (1999) were the first to use ATSR-2 data to determine surface reflectance based on a simple physical model of light scattering for the dual-angular sampling of the instrument. The method is based on the angular constraint, which can be used to separate the surface BRDF from the atmospheric aerosol properties without a priori information on the land surface properties. This model can be used to estimate the degree of atmospheric contamination for a particular set of reflectance measurements and to find the atmospheric parameters which allow retrieval of realistic surface reflectances (Grey and North, 2009). North et al. (1999) report that the corresponding mean absolute error in reflectance estimation, defined for a nadir observation at $555 \mathrm{~nm}$, is less than 0.01 . The algorithm was applied to the dual-view AATSR data for a number of sites around the world to test its performance over a range of land covers and aerosol types. Results show good agreement $\left(r^{2}=0.70\right.$ for all sites combined) between the AATSR-derived estimates of AOD and sun photometer measurements (Grey et al., 2006b). The retrieval performs best over vegetated land covers for biomass burning aerosol types.

The objective of the current paper is to describe and evaluate a different method for the retrieval of the land surface reflectance which is based on the use of the dual-view ca- 
pability in order to obtain the AOD nearly independently of the surface reflectance and thus use this value for atmospheric correction in the retrieval of the latter, as described in Sect. 3.1. This method is essentially different from that presented by North et al. (2009).

The paper is structured as follows. The AATSR instrument is introduced in Sect. 2. In Sect. 3 the algorithm for the retrieval of AOD and surface reflectance is presented. In addition, the data sets used for validation and comparison are described. Results are presented in Sect. 4 and validated in Sect. 5. As an example, seasonal variations in surface reflectance along a transect over Australia are discussed in Sect. 6. Conclusions are presented in Sect. 7.

\section{The AATSR instrument}

The Advanced Along-Track Scanning Radiometer (AATSR) onboard the ENVISAT satellite (2002-2012) and its precursor ATSR-2 onboard the ERS-2 (providing level 1 data which are used for aerosol retrieval for the period 19952003) are dual-view instruments with across-track conical scanning for both views. One view is near nadir and the other one is at a $55^{\circ}$ forward angle. The time between the two views is $150 \mathrm{~s}$ along track. The nominal resolution at nadir is $1 \mathrm{~km} \times 1 \mathrm{~km}$ and the swath width is $512 \mathrm{~km}$, which results in global coverage in 5-6 days. AATSR has three wavebands in the visible-near infrared (centered near 555, 659 and $865 \mathrm{~nm}$ ) and four bands in the infrared (centered near $1610,3700,10850,12000 \mathrm{~nm}$ ). The ADV algorithm uses the 555, 659 and $1610 \mathrm{~nm}$ wavebands for the aerosol retrieval over land.

ATSR-2 and AATSR were developed to provide highaccuracy measurements of sea surface temperature for use in studies of global climate change. However, both instruments are also successfully used for the retrieval of aerosol properties in the atmosphere over land and ocean (Veefkind and de Leeuw, 1998; Veefkind et al., 1998; Grey et al., 2006a; Robles-Gonzalez et al., 2000, 2003; Thomas et al., 2009; Sundström et al., 2012; Kolmonen et al., 2013; de Leeuw et al., 2013).

\section{Methods}

The AATSR surface reflectance retrieval is based on using independently retrieved AOD as an atmospheric correction of the TOA reflectance measured with AATSR retrieved with the AATSR dual-view retrieval algorithm ADV (see Sect. 3.1 and, for example, Veefkind et al., 1998; Kolmonen et al., 2013, for a description of the most recent ADV version). The basic principle of the aerosol retrieval is to match the AATSR-measured TOA reflectance, in cloud-free conditions, to modeled reflectance at the same wavelengths by minimizing the error function. The modeled reflectance is computed with a radiative transfer model for the transmission of so- lar radiance through the atmosphere which includes a variety of aerosol models. The aerosol model used in the ADV is a mixture of four aerosol components (de Leeuw et al., 2013).

The quality of the AOD retrieved using ADV is similar to that from other AATSR algorithms or to that from MODIS and MISR (de Leeuw et al., 2013). Hence, in view of its measurement with the same instrument, the ADV-retrieved AOD is a good choice for atmospheric correction in the retrieval of land properties using AATSR data. The application of ADV to determine AOD and surface reflectance is described in Sect. 3.1. The results are validated using data from the AERONET and ASRVN database, which is described in Sect. 3.2. ADV-retrieved surface reflectance is compared with the MODIS albedo/BRDF product, which is described in Sect. 3.3.

\subsection{ADV retrieval algorithm}

The TOA reflectance measured by radiometers is the sum of the surface and atmospheric reflectances, and hence the retrieval of the surface reflectance requires an effective decoupling of the surface and atmospheric effects, also referred to as atmospheric correction. Cloud reflectance dominates in the TOA signal, and therefore only cloud-free conditions are considered. Thus strict cloud screening is required. ADV utilizes the semiautomatic algorithm to discriminate between cloudy and cloud-free pixels developed by Koelemeijer et al. (2001). This procedure has been automated by RoblesGonzalez et al. (2003), who developed a threshold method applied to histograms of reflectances measured in an ATSR2 scene (see also Curier et al., 2009). Four tests are applied using brightness temperatures in the thermal infrared and reflectances and reflectance ratios in the visible and nearinfrared channels. A pixel is classified as cloud-free only if all tests indicate that no cloud is present. Furthermore, since the retrieval results indicate the possible occurrence of clouds due to imperfect cloud-screening, a post-processing step is applied after AOD retrieval as described in Kolmonen et al. (2013).

The measured TOA reflectance $\rho$ is given by Eq. (1) (Chandrasekhar, 1960; Veefkind and de Leeuw, 1998; Kolmonen et al., 2013):

$$
\begin{aligned}
& \rho\left(\mu_{1}, \mu, \phi, \lambda\right)=\rho_{\mathrm{a}}\left(\mu_{1}, \mu, \phi, \lambda\right) \\
& +\frac{T\left(\mu_{1}, \mu, \phi, \lambda\right) \rho_{\mathrm{s}}\left(\mu_{1}, \mu, \phi, \lambda\right)}{1-\mathrm{s}(\lambda) \rho_{\mathrm{s}}(\lambda)},
\end{aligned}
$$

where $\rho_{\mathrm{a}}$ is the atmospheric reflectance due to aerosol particles and gases $\left(\rho_{\mathrm{a}}=\rho_{\text {aerosol }}+\rho_{\text {gas }}\right), \rho_{\mathrm{s}}$ is the surface reflectance, $T$ is the product of downward and upward atmospheric total transmittance, $\mathrm{s}$ is the spherical albedo of the atmosphere, and $\lambda$ is the wavelength. The Sun-satellite geometry is determined by the solar zenith angle $\mu_{1}$, the viewing (satellite) zenith angle $\mu$, and the relative azimuth angle between the Sun and the satellite $\phi$. Usually, the surface albedo 
instead of the surface reflectance is used in the denominator. The choice of using the surface reflectance $\rho_{\mathrm{s}}$ together with the spherical albedo $s$ in the denominator of the second term of Eq. (1) allows surface reflectance to be solved as described below. The choice made here implies that surface reflectance is assumed to be Lambertian, i.e., surface reflectance is isotropic. However, as applied to anisotropic surface, it is not rigorous. The rigorous analytic solution (not used in ADV) was provided in Lyapustin and Knyazikhin (2001).

The AATSR instrument has two views. In the ADV aerosol retrieval algorithm the surface reflectance is accounted for by using both views and assuming that the ratio of the forward and nadir surface reflectance (the so-called $k$ ratio) is independent of wavelength for the employed AATSR wavelengths (Flowerdew and Haigh, 1995). The $k$ ratio is determined at $1610 \mathrm{~nm}$ assuming that the contribution of aerosols and gases to the TOA reflectance is negligible at this wavelength. This assumption does not hold in the presence of large aerosol particles, such as desert dust or sea spray. For other types of aerosol, consisting predominantly of submicron particles, the $k$ ratio can be determined at $1610 \mathrm{~nm}$ and used to eliminate surface effects to the TOA reflectance and thus retain the path radiance. The gaseous contribution can be estimated using the atmospheric pressure and temperature, and thus the aerosol contribution is retained. The AOD is retrieved by comparison of the aerosol reflectance with modeled reflectance, determined for a number of aerosol models, each consisting of a mixture of four different aerosol components (de Leeuw et al., 2013). The optimal aerosol component is determined by least-squares fitting for three wavelengths $(555,659$ and $1610 \mathrm{~nm})$ simultaneously. The $865 \mathrm{~nm}$ wavelength is not used over land as the $k$ ratio assumption does not hold.

The determined AOD, together with the Rayleigh (gaseous) reflectance, can be used to provide atmospheric correction needed for the retrieval of the surface reflectance. It is straightforward to solve the surface reflectance $\rho_{\mathrm{s}}$ from Eq. (1):

$$
\begin{aligned}
& \rho_{\mathrm{s}}\left(\mu_{1}, \mu, \phi, \lambda\right)= \\
& -\frac{\rho\left(\mu_{1}, \mu, \phi, \lambda\right)-\rho_{\mathrm{a}}\left(\mu_{1}, \mu, \phi, \lambda\right)}{T\left(\mu_{1}, \mu, \phi, \lambda\right)+\left(\rho\left(\mu_{1}, \mu, \phi, \lambda\right)-\rho_{\mathrm{a}}\left(\mu_{1}, \mu, \phi, \lambda\right)\right) s(\lambda)} .
\end{aligned}
$$

The determined surface reflectance is an indirect but nearly independent retrieval product. The only assumptions used in this procedure are (1) Lambertian surface reflectance and (2) $k$ ratio assumption (the ratio of the surface reflectances in the forward and nadir views are independent of wavelength and the $k$ ratio can be determined at $1610 \mathrm{~nm}$, where the effect of aerosol particles is assumed to be negligible).

\subsection{ASRVN}

Satellite product validation relies on the availability of independent data for the same quantity, usually from ground- based measurements. For the validation of satellite-retrieved aerosol properties, data provided by the ground-based sun photometer network AERONET (Holben et al., 1998) are commonly used. For the validation of satellite-derived surface reflectance the AERONET-based Surface Reflectance Validation Network (ASRVN) database (Wang et al., 2009) has been developed. ASRVN is an operational processing system which uses ancillary AERONET aerosol and water vapor data, while MODIS TOA measurements are used for atmospheric correction (Wang et al., 2009).

The ASRVN products include the bidirectional reflectance factor (BRF, often called surface reflectance), spectral albedo, parameters used in the RossThick-LiSparse (RTLS) BRF model (Lucht et al., 2000; see Sect. 3.3 for more details) and a theoretical normalized BRF (NBRF) computed for a standard viewing geometry, $\mathrm{VZA}=0^{\circ}$ and $\mathrm{SZA}=45^{\circ}$ for MODIS wave bands 1-7 (http://modis.gsfc.nasa.gov/about/ specifications.php). For each AERONET site, ASRVN products are stored in a gridded format with a $1 \mathrm{~km}$ resolution for an area of $50 \mathrm{~km} \times 50 \mathrm{~km}$. ASRVN is widely used for product validation (e.g., Lyapustin et al., 2007; Wang et al., 2010; Ramon, 2011) and long-term trend and stability studies (Wang et al., 2009). The main sources of errors in the ASRVN algorithm are the residual cloudiness and variation in MODIS pixel size with scan angle, which increases by a factor of 8 from nadir to the edge of scan (Wang et al., 2011). The second is important in regions with high surface heterogeneity.

ASRVN data are available for the period from February 2000 until May 2008. In the current study ASRVN has been used to validate the ADV-retrieved surface reflectance for the whole year of 2007. RTLS BRF model parameters have been used to calculate the ASRVN surface reflectances for the AATSR solar geometry, at the wavelengths of 555 and $659 \mathrm{~nm}$.

To examine the performance of the retrieval for different surface types, ASRVN locations have been subjectively divided (using the AERONET site description and images) into eight groups, according to the land type and industry/population in the surroundings: forest, plane or steppe, desert, coastal site, urban highly populated industrial (urban_hpi), urban, mountain (elevated $>1000 \mathrm{~km}$ ) and tundra. It is noted that no AATSR/ASRVN collocated pixels over tundra have been found for the 2007 study period. Statistical analysis has been performed to the whole data set and for different surface types. Results are presented in Sect. 5.1.

\subsection{MODIS BRDF product}

The MOD43B1 BRDF/Albedo Model Parameters Product (MODIS BRDF/Albedo product, http://modis.gsfc.nasa.gov/ data/atbd/atbd_mod09.pdf) supplies the weighting parameters associated with the RTLS BRDF model that best describes the anisotropy for each pixel (Gao et al., 2005). Three parameters - (1) isotropic scattering, (2) radiative transfer type volumetric scattering (from horizontally homogeneous 


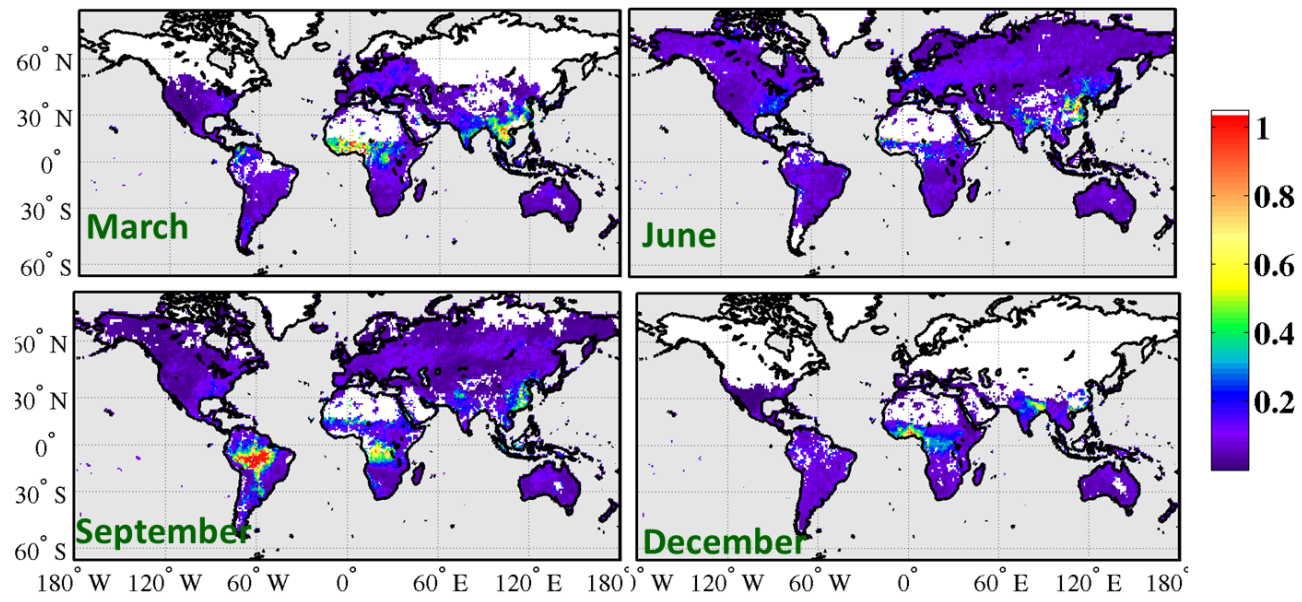

Figure 1. Monthly aggregated AOD at $555 \mathrm{~nm}$ retrieved with ADV for March, June, September and December 2007.
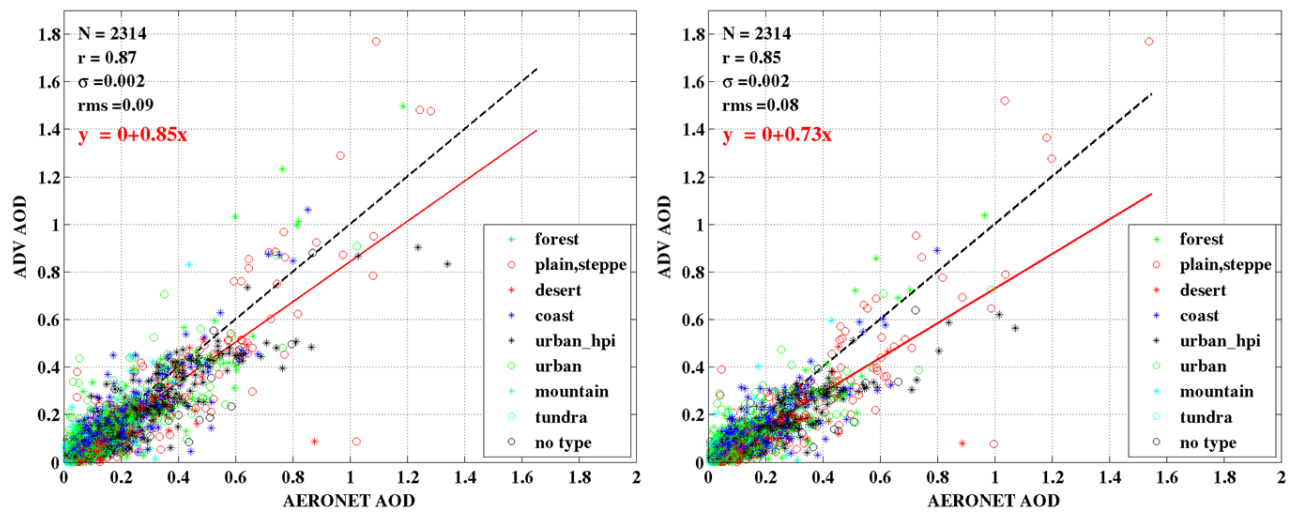

Figure 2. Validation of the AOD at $555 \mathrm{~nm}$ (left) and at $659 \mathrm{~nm}$ (right) retrieved from AATSR using ADV against AERONET AOD for year 2007. Colors and symbols relate to different surface types as explained in the legend.

leaf canopies), and (3) geometric-optical surface scattering (from scenes containing three-dimensional objects) - are provided for all MODIS spectral bands as well as for three broad bands $(0.3-0.7,0.7-5.0$ and $0.3-5.0 \mu \mathrm{m})$. These parameters (e.g., Roujean et al., 1992) can be used to reconstruct the surface anisotropic effects and thus correct directional reflectance to any needed view geometry.

The BRDF kernel fitting method has been validated by comparing ground-based measurements to reflectance remotely retrieved from other satellites. This comparison leads to the conclusion that the difference is small enough $( \pm 0.05)$ for accurate climate modeling (Lucht et al., 2000). The accuracy of the MODIS albedo products using two sets of coincident field measurements - SURFRAD stations and CART/SGP area - has been investigated by Jin et al. (2003). In both networks, the root-mean-square error (RMSE) was less than 0.0177 and a relatively bias of 0.004 was observed for the MODIS albedo products. The reason for the uncertainties in the MODIS spectral surface albedo is the Lamber- tian approximation, which "flattens" the BRDF shape (Lee et al., 1986; Wang et al., 2010).

The MODIS BRDF model also captures the solar zenith angle dependence of the surface albedo as indicated in field measurements. For the broad range of mixed vegetation and structural types, the overall accuracy of the MODIS albedo remains within a $\pm 10 \%$ margin of error for all solar zenith angles (Román et al., 2013). However, the derived surface reflectance is underestimated at high solar or view zenith angles, where BRDF is high, and is overestimated at low zenith angles, where BRDF is low (Liu et al., 2009).

\section{Results}

\subsection{ADV aerosol optical depth}

The AOD retrieved using ADV is used as atmospheric correction to obtain the surface reflectance. Therefore the AOD quality is a key factor which determines the quality of the surface reflectance $\mathrm{ADV}$ product. 


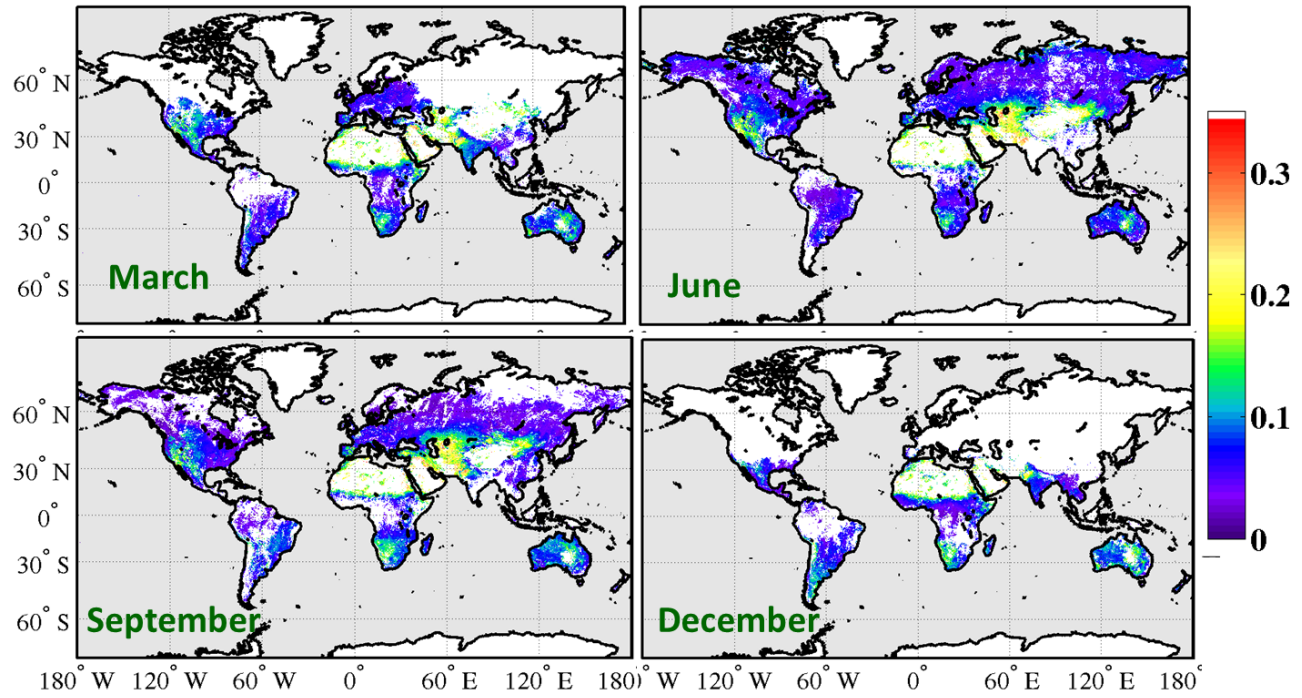

Figure 3. Monthly aggregated surface reflectance at $555 \mathrm{~nm}$ retrieved from AATSR with ADV for March, June, September and December 2007.
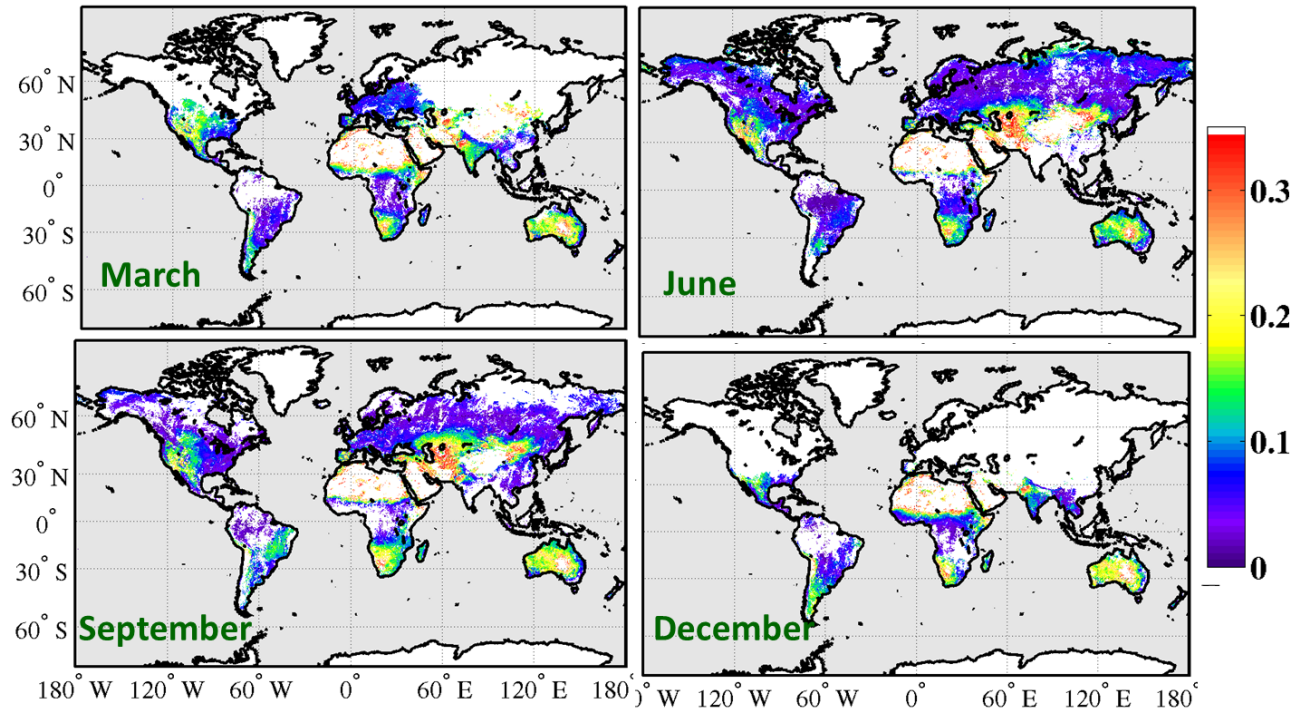

Figure 4. Monthly aggregated surface reflectances at $659 \mathrm{~nm}$ retrieved from AATSR with ADV for March, June, September and December 2007.

Monthly maps of the retrieved AOD at $555 \mathrm{~nm}$ for March, June, September and December 2007 are shown in Fig. 1. ADV does not retrieve AOD for solar zenith angles larger than $75^{\circ}$, which relates to radiative transfer model limitations. AOD over other bright surfaces (measured TOA reflectance at $1610 \mathrm{~nm}>0.45$ ), such as deserts and snow, are also not shown here because there are some thus far unresolved issues with the quality of the retrieval results in such conditions. AOD patterns for $659 \mathrm{~nm}$ (not shown here) are similar to those at $555 \mathrm{~nm}$.

The detailed validation of ADV is presented in de Leeuw et al. (2013) and Holzer-Popp et al. (2013) for 4 and 1 months of data, respectively, in 2008. In this study we use data for 2007 because ASRVN data that have been used for ADV-retrieved surface reflectance validation are available until May 2008. Validation results for the ADV-retrieved AOD at 555 and $659 \mathrm{~nm}$ for the whole year 2007 are presented in Fig. 2 as scatterplots of the ADV-retrieved versus AERONET-retrieved AOD at $555 \mathrm{~nm}$ (left) and at $659 \mathrm{~nm}$ (right). For 2314 collocated points, the correlation coefficients for $555 / 659 \mathrm{~nm}$ are $r=0.87 / 0.85$, RMSE $=0.09 / 0.08$, and $\sigma=0.002$ (for both 555 and $659 \mathrm{~nm}$ ). These metrics underline the confidence in the ADV-retrieved AOD and the use 


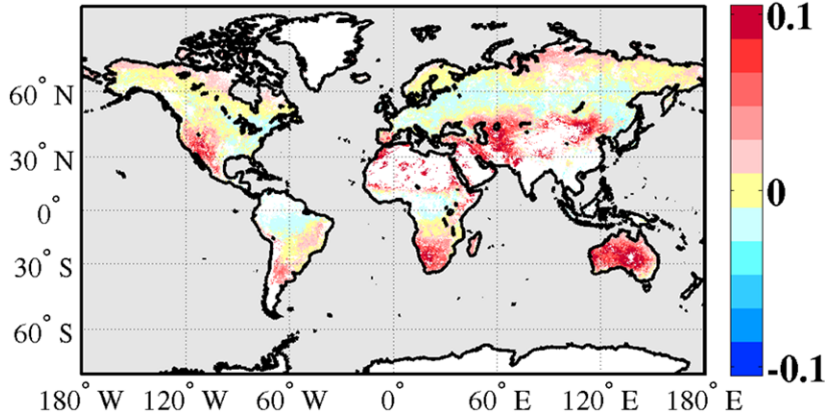

Figure 5. Difference between the monthly aggregated ADVretrieved surface reflectances at 659 and $555 \mathrm{~nm}$ for June 2007.

of these data for atmospheric correction in determination of surface reflectance.

\subsection{ADV surface reflectance}

The land surface reflectance has been retrieved from AATSR for the wavelengths of 555 and $659 \mathrm{~nm}$ for the whole year of 2007. Examples of the surface reflectance are presented in Fig. 3, for $555 \mathrm{~nm}$, and Fig. 4, for $659 \mathrm{~nm}$, as monthly aggregated maps for March, June, September and December.

Spatial coverage varies from month to month due to the seasonal changes in solar angle and due to the occurrence of snow and ice. AOD cannot, in general, be reliably retrieved with the ADV over surfaces with very high reflectance (see Sect. 3.1), such as over snow and ice, and thus cannot be used for atmospheric correction.

Variations in the land surface reflectance for the same area relate mainly to the seasonality in the vegetation cover and agriculture/forestry activity.

Surface reflectance patterns are similar for both 555 and $659 \mathrm{~nm}$, although obviously spectral differences exist related to the type of land cover. This is illustrated in Fig. 5, where the differences between the land surface reflectances retrieved at 555 and $659 \mathrm{~nm}$ are shown for June 2007. For the retrieved areas, the global difference in the surface reflectance retrieved for these wavelengths is about $2 \%$. The differences in the surface reflectances at 555 and $659 \mathrm{~nm}$ are smaller for dark surfaces (forests, cultivated land surfaces) $(0-0.02$, or $0-2 \%)$ than for bright surfaces such as steppe or mountains (up to $8-10 \%$ ). These results agree qualitatively with results presented by Briegleb et al. (1985).

The validation of the surface reflectance results using the ASRVN data is presented in Sect. 5.1; their comparison with MODIS data is shown in Sect. 5.2.

\section{ADV surface reflectance validation and comparison}

Validation of land surface products is important because their accuracy is critical to the scientific community for various applications. The value of the product for science applica- tions and research depends on the accuracy of the data. Thus, validation of the product is needed for quality estimation. Climate modeling requires albedo with an absolute accuracy of \pm 0.05 according to Henderson-Sellers and Wilson (1983) and of \pm 0.02 according to Sellers (1995).

\subsection{ADV-retrieved surface reflectance validation with ASRVN}

For the validation of the ADV-retrieved surface reflectance with the ASRVN data, RTLS BRF model parameters have been used to calculate the ASRVN surface reflectances for the AATSR Sun-satellite viewing geometry at wavelengths of 555 and $659 \mathrm{~nm}$, for an area of $50 \mathrm{~km} \times 50 \mathrm{~km}$ around each AERONET station. Only the ASRVN data which were obtained within $1 \mathrm{~h}$ of the AATSR overpass have been used. ADV-retrieved surface reflectances have been averaged for the same area. Thus, uncertainty related to "point-to-pixel" comparison has been minimized. However, the validation results might still be influenced by uncertainties related to biophysical, spatial, and seasonal signatures and inhomogeneity (Román et al., 2009).

Scatterplots of the ADV and ASRVN surface reflectance at both wavelengths are presented in Fig. 6 . The statistical metrics for the whole data set (553 collocated data points) for the wavelengths of $555 / 659 \mathrm{~nm}$ are as follows: $r=0.8 / 0.9$, RMSE $=0.02 / 0.03$ and slope $=0.91 / 1.08$. The standard deviation $(0.001)$ is the same for both wavelengths.

The collocated data pairs have further been classified according to land cover (see Sect. 3.2). For each subset of land cover data, the statistical metrics for the correlation between ADV and ASRVN reflectances have been computed using linear regression to obtain the standard deviation $(\sigma)$, correlation coefficient $(r)$, root mean square error (RMSE), slope and bias (see Table 1). The highest correlation occurs for brighter surfaces, such as steppe $(0.90 / 0.95$ for $555 / 659 \mathrm{~nm})$. The lowest correlation $(0.31 / 0.61)$ is obtained for coastal sites, where the $50 \mathrm{~km} \times 50 \mathrm{~km}$ area may include a mixed ocean-land surface. The standard deviation for each surface type and wavelength is between 0.002 and 0.003 . ADV slightly underestimates the reflectance at $555 \mathrm{~nm}$ for brighter (mountain, steppe) surfaces. At $659 \mathrm{~nm}$ the overestimation is minor (bias $=0$; slope $=1.08$ ). Note that validation is limited by the maximum surface reflectance of 0.35 at $555 \mathrm{~nm}$ in the ASRVN database.

One of the reasons for the disagreement between ADV and ASRVN-retrieved reflectance is likely that the ASRVN polynomial coefficients used to compute the directional reflectance are derived using the MODIS TOA measurements accumulated for a 16-day interval as the atmospheric correction. Even though the variations in the exact results with aerosol optical depth are small, they affect the retrieval accuracy by a few percent (Lucht et al., 2000). Another reason for the disagreement is that the surface reflectance measured from a satellite will not be purely bidirectional, but will in- 

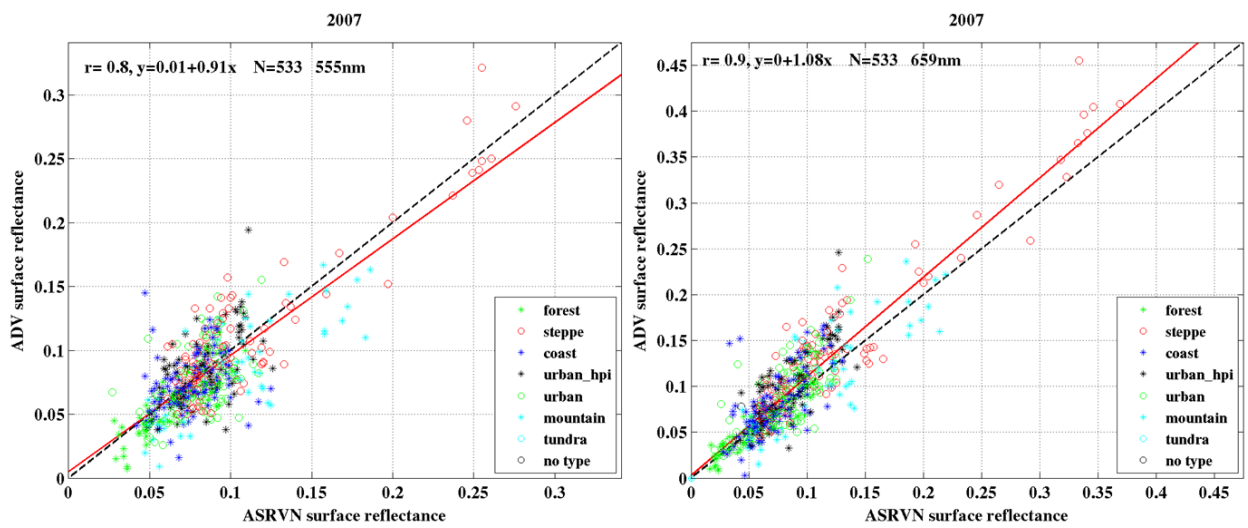

Figure 6. Scatterplots of ADV-retrieved surface reflectances versus surface reflectances derived from collocated ASRVN albedo matched to the AATSR solar zenith (SZ) angles for wavelengths of $555 \mathrm{~nm}$ (left) and $659 \mathrm{~nm}$ (right). Colors and symbols relate to different surface types; see legend.

Table 1. Statistical metrics for the regression between the ADV and ASRVN surface reflectances at 555/659 nm for different surface types and land use ( $N$ - number of cases; $r$ - correlation coefficient; $\sigma$ - standard deviation; RMSE - root-mean-square error; and bias and slope - parameters for linear regression)

\begin{tabular}{lrlllll}
\hline & $N$ & $r$ & $\sigma$ & RMSE & Bias & Slope \\
\hline forest & 64 & $0.84 / 0.91$ & $0.002 / 0.002$ & $0.01 / 0.01$ & $0.00 / 0.00$ & $0.90 / 1.06$ \\
steppe/plain & 111 & $0.90 / 0.95$ & $0.002 / 0.003$ & $0.02 / 0.03$ & $0.00 / 0.01$ & $0.98 / 1.09$ \\
coast & 109 & $0.31 / 0.66$ & $0.002 / 0.002$ & $0.02 / 0.03$ & $0.04 / 0.01$ & $0.42 / 0.97$ \\
urban_hpi & 77 & $0.61 / 0.81$ & $0.003 / 0.003$ & $0.02 / 0.03$ & $0.01 /-0.01$ & $0.91 / 1.26$ \\
urban & 117 & $0.51 / 0.72$ & $0.002 / 0.002$ & $0.02 / 0.03$ & $0.01 / 0.01$ & $0.79 / 1.03$ \\
mountain & 54 & $0.79 / 0.82$ & $0.003 / 0.004$ & $0.03 / 0.03$ & $0.00 / 0.01$ & $0.81 / 0.94$ \\
all & 533 & $0.80 / 0.90$ & $0.001 / 0.001$ & $0.02 / 0.03$ & $0.01 / 0.00$ & $0.91 / 1.08$ \\
\hline
\end{tabular}

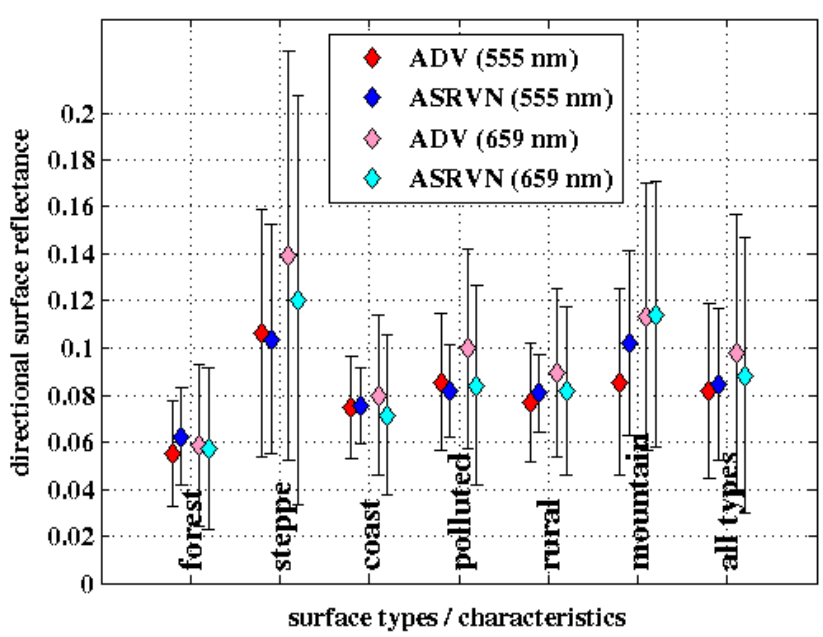

Figure 7. Mean (diamonds) and standard deviation (error bars) ADV surface reflectance (red, pink) and matched to the AATSR solar zenith (SZ) angles (blue, turquoise) for wavelengths of $555 \mathrm{~nm}$ (red, blue) and $659 \mathrm{~nm}$ (pink, turquoise), averaged for different surface types. clude a diffuse to direction component which depends on the turbidity of the atmosphere (Schaepman-Strub et al., 2006).

The absolute (U_abs) and relative (U_rel) uncertainties based on the validation have been calculated for each land cover type at both 555 and $659 \mathrm{~nm}$, using

$$
\begin{aligned}
& U_{-} \operatorname{abs}(\lambda)=r_{\mathrm{ADV}, \lambda}-r_{\mathrm{ASRVN}, \lambda}, \\
& U_{-} \text {rel }(\lambda)=\frac{r_{\mathrm{ADV}, \lambda}-r_{\mathrm{ASRVN}, \lambda}}{\left(r_{\mathrm{ADV}, \lambda}+r_{\mathrm{ASRVN}, \lambda}\right) / 2} \times 100 \% .
\end{aligned}
$$

The absolute uncertainty for each of the land cover types and for all types together (Table 2) is about 0.02 for surface reflectance at both 555 and $659 \mathrm{~nm}$. The highest relative uncertainty (Table 2) at $555 \mathrm{~nm}$ is observed for forest and mountain regions (27.7 and $28.9 \%$, respectively), and the lowest for steppe $(2.1 \%)$. At $659 \mathrm{~nm}$ the uncertainty is more evenly distributed for all land types (10-13\%).

We also studied the dependence of uncertainties on aerosol loading. For $555 \mathrm{~nm}$, for lower $(<0.2)$ and higher $(>0.2)$ AOD, the uncertainties for all pixels are 12.8 and $12.6 \%$, respectively. At $659 \mathrm{~nm}$, the uncertainty for low AOD is higher compared to the uncertainty for high-AOD cases (9.5 and $-2.1 \%$, respectively). 


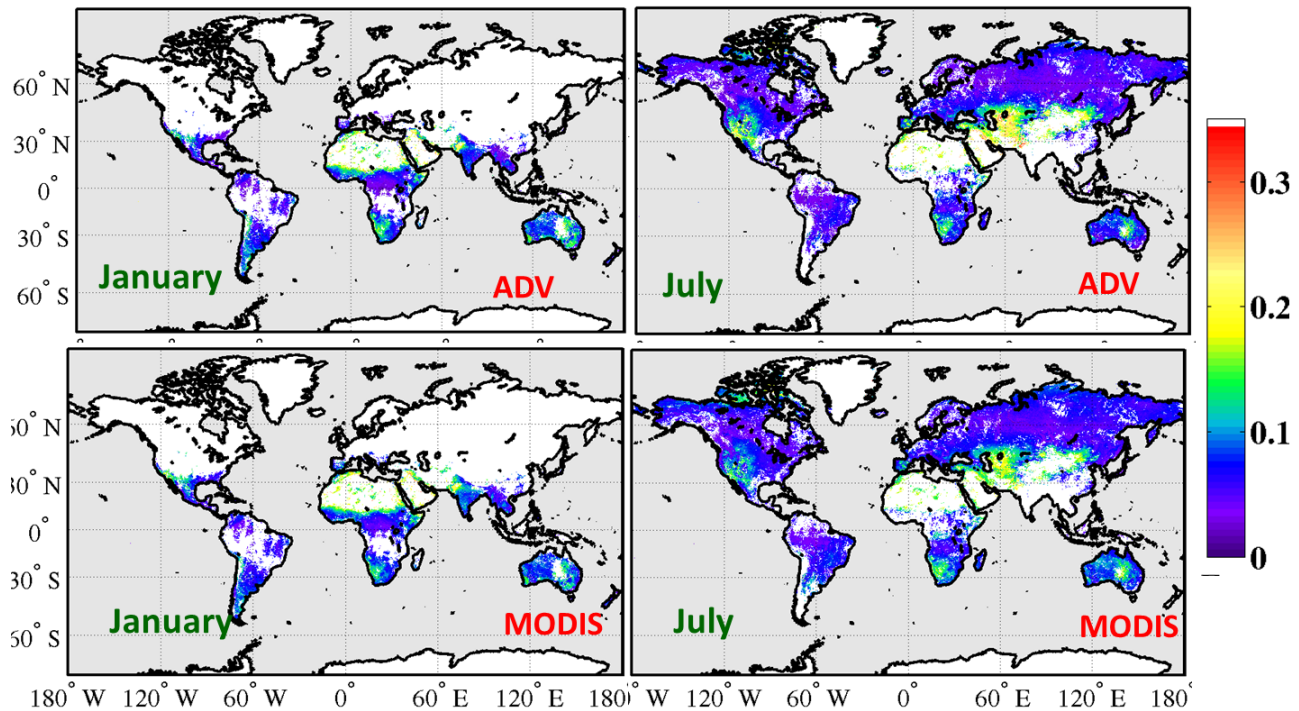

Figure 8. ADV (upper panel) and MODIS-derived surface reflectances matching the AATSR viewing geometry (lower panel) for $555 \mathrm{~nm}$ for January (left) and July (right).
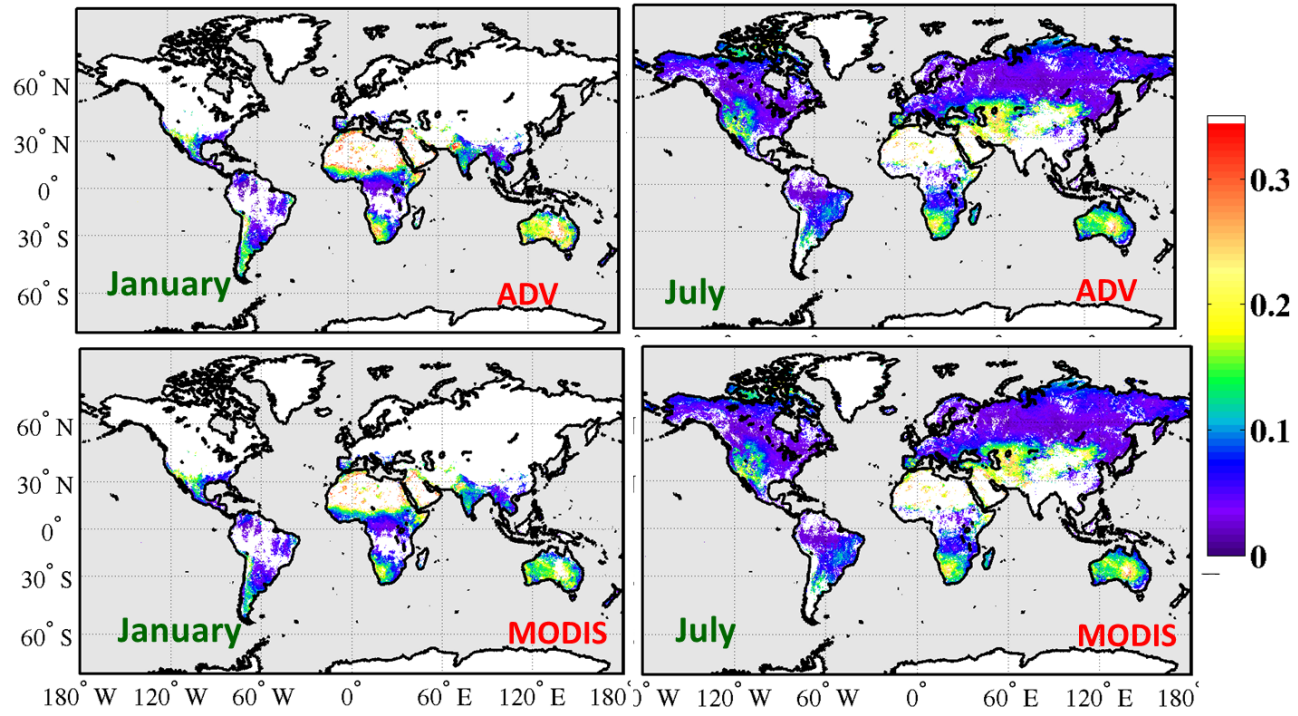

Figure 9. ADV (upper panel) and MODIS-derived surface reflectance matching the AATSR viewing geometry (lower panel) for 659 nm for January (left) and July (right).

In Fig. 7 we compare the ADV- and ASRVN-averaged surface reflectance at 555 and $659 \mathrm{~nm}$ for each land cover type. Land surface reflectance varies considerably among the surface types.

\subsection{Comparison of ADV-retrieved surface reflectance with MODIS data}

Intercomparison of products from different sensors offers a simple way to evaluate temporal and spatial consistency in addition to the local validation points offered by ASRVN. For the comparison of the ADV-retrieved surface re- flectance with MODIS products, MODIS reflectances at the AATSR solar zenith angles have been derived from the MODIS albedo using RTLS BRDF model parameters for collocated pixels. This was done only for snowfree pixels selected by using the MODIS product "Percent snow" from the product MCD43C3 (https://lpdaac.usgs. gov/products/modis_products_table/mcd43c3). Monthly aggregated surface reflectance maps for January and June are shown in Figs. 8 and 9 for 555 and 659 nm, respectively, for ADV (top) and MODIS (bottom).

The surface reflectance patterns retrieved with ADV and MODIS are similar. The averaged global difference between 

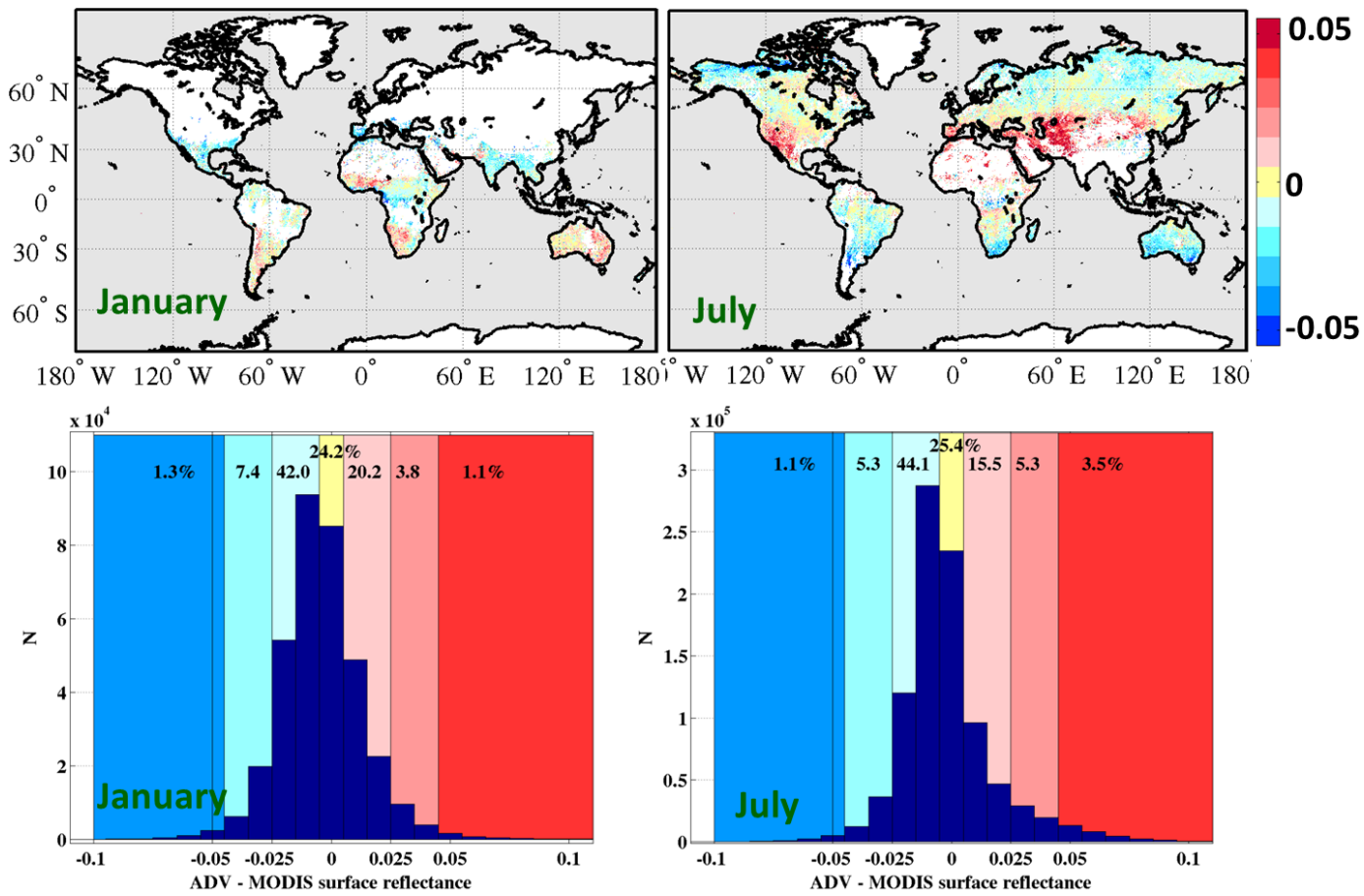

Figure 10. Monthly aggregated maps (upper panel) and histograms (lower panel) of the differences between ADV-retrieved and MODISderived surface reflectances at $555 \mathrm{~nm}$ for January (left) and July (right). Numbers in the histogram bins (colored in blue, yellow and red) at the top of the histograms are the percentages of hits of the differences to bins.
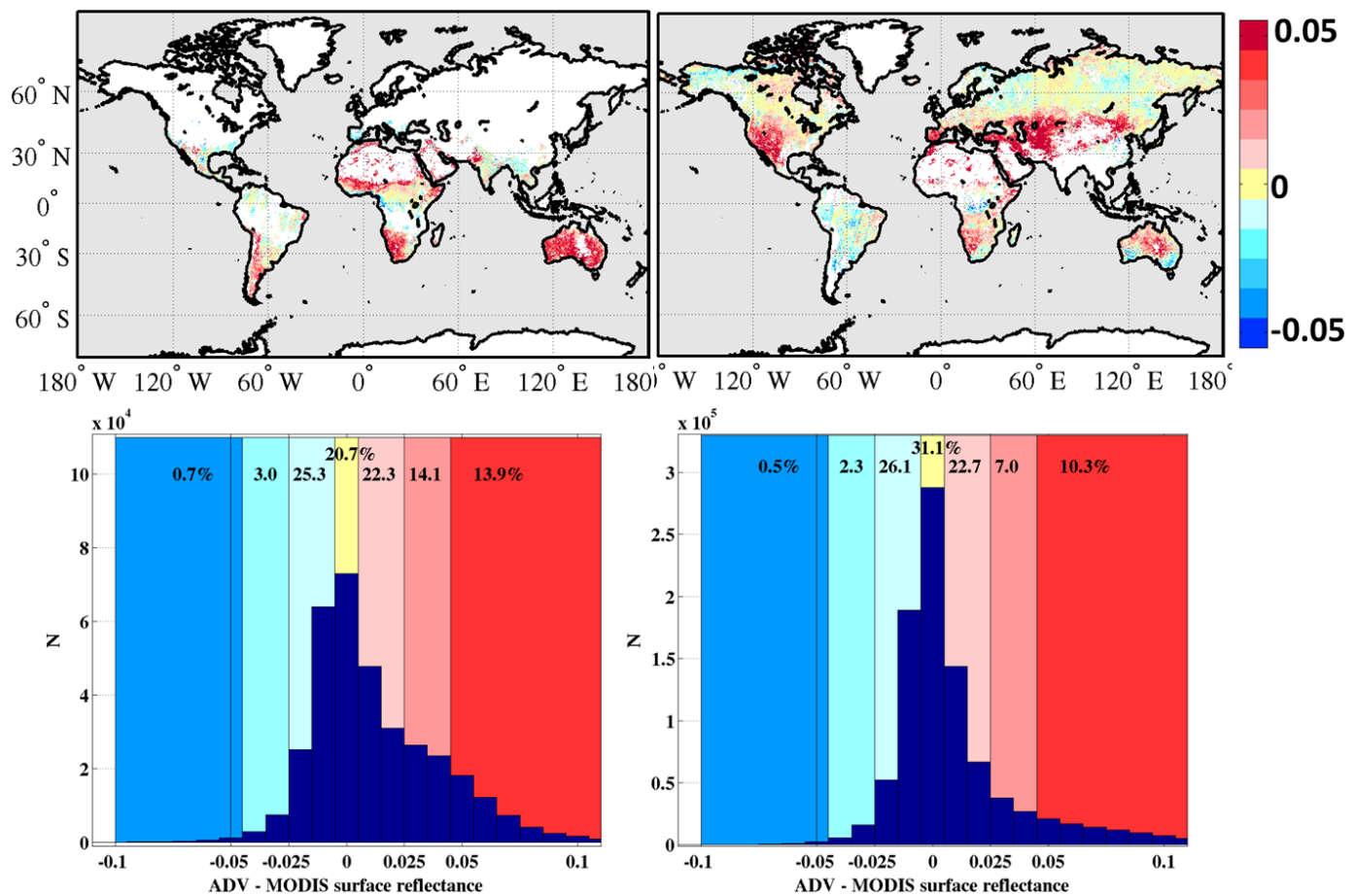

Figure 11. Monthly aggregated maps (upper panel) and histograms (lower panel) of the differences between ADV-retrieved and MODISderived surface reflectances at $659 \mathrm{~nm}$ for January (left) and July (right). Numbers in the histogram bins (colored in blue, yellow and red) at the top of the histograms are the percentages of hits of the differences to bins. 

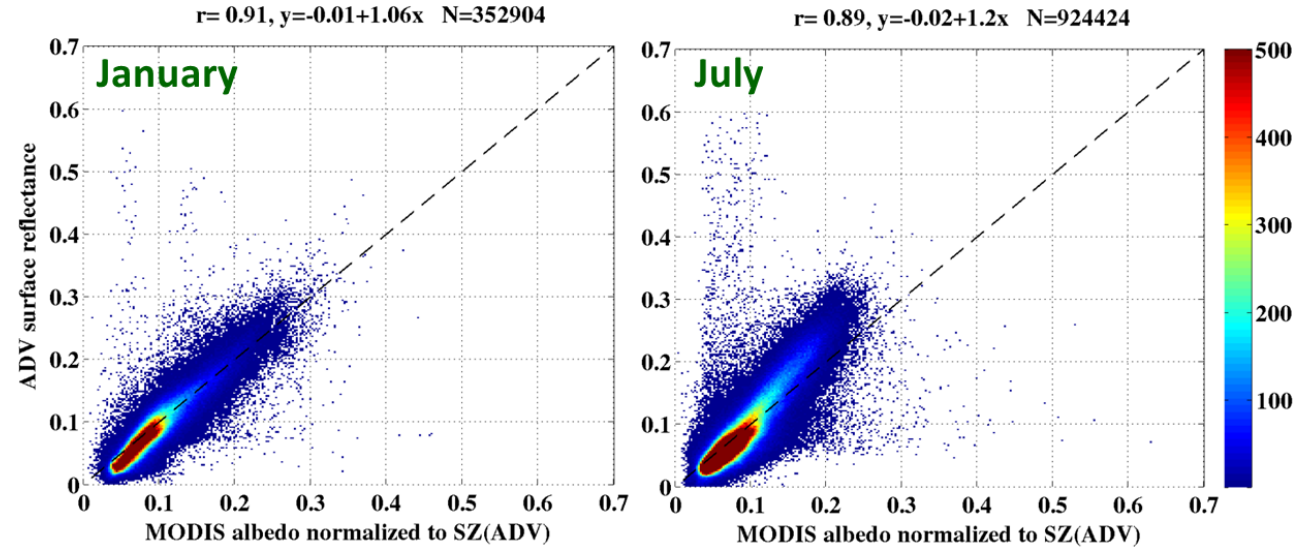

Figure 12. ADV vs MODIS point-to-point surface reflectance for 555nm for January (left) and July (right). Color (legend) represents the frequency of the observations.
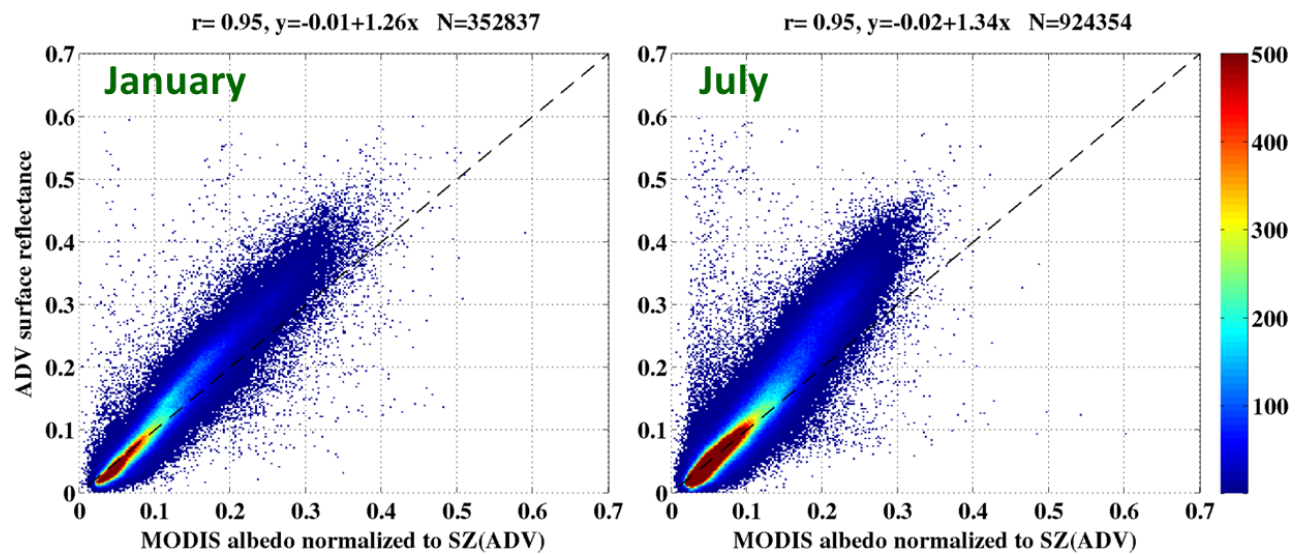

Figure 13. ADV vs MODIS point-to-point surface reflectances for $659 \mathrm{~nm}$ for January (left) and July (right). Color (legend) represents the frequency of the observations.

ADV and MODIS is very small (0.01). However, there are differences as illustrated in Figs. 10 and 11. Over bright surfaces the surface reflectance at $555 \mathrm{~nm}$ retrieved using the ADV is slightly higher than that from MODIS, but $97 \%$ of the pixels agree to within 0.05 and $86 \%$ agree to within 0.025 . For $659 \mathrm{~nm}$ the differences are slightly larger. For darker surfaces (forest, tundra), the ADV-retrieved surface reflectance is slightly lower $(0.01-0.02)$ than that from MODIS. These differences are similar to those observed in the validation of the ADV-retrieved surface reflectances against the ASRVN data (Sect. 5.1); this would indicate imperfections in the ADV retrieval. However, the observed differences could also in part be due to the limitations of the RTLS BRDF model (see discussion in Sects. 3.2 and 3.3).

Very high ADV-retrieved surface reflectances (ADVMODIS $>0.4$, less than $0.01 \%$ of total number of pixels retrieved as shown in the histograms in Figs. 10 and 11) occur in coastal regions and in South America, where ADV might have problems with cloud detection. Low ADV-retrieved sur- face reflectances (MODIS-ADV $>0.4$, less than $0.001 \%$ of total number of pixels retrieved in winter months; see histograms in Figs. 10 and 11) are located in northern regions with possible snow melt, where the MODIS 16-day aggregated product is indicated to be snow-free, although the actual MODIS surface reflectance is high $(0.4-0.8)$. In that case the problem would not be with ADV but with the MODIS data. Another explanation for MODIS' overestimation in high-latitude regions is that the use of the MODIS product is recommended only for applications with solar zenith angles smaller than $70-75^{\circ}$ (Liu et. al., 2009). The ADV-retrieved surface reflectance may also be low due to effects of cloud shadows, which are not identified and thus not accounted for in the algorithm.

Scatterplots of the ADV-retrieved surface reflectance at $555 \mathrm{~nm}$ compared with MODIS data for January and June are shown in Fig. 12. Similar plots for $659 \mathrm{~nm}$ are shown in Fig. 13. The number of collocated points, the $r$ value and the regression equation are given at the top of each plot. The 
Table 2. The absolute (U_abs) and relative (U_rel) uncertainties between ADV and ASRVN surface reflectances at 555/659 nm, calculated for all collocated pixels in different surface type groups.

\begin{tabular}{llllllll}
\hline & forest & steppe & coast & urban_hpi & urban & mountain & all \\
\hline U_abs & $0.01 / 0.01$ & $0.02 / 0.03$ & $0.02 / 0.02$ & $0.02 / 0.02$ & $0.02 / 0.02$ & $0.02 / 0.02$ & $0.02 / 0.02$ \\
U_rel, \% & $27.2 / 12.7$ & $2.1 / 9.6$ & $9.1 / 13.8$ & $8.0 / 13.3$ & $13.1 / 10.9$ & $28.9 / 13.0$ & $12.7 / 0.06$ \\
\hline
\end{tabular}

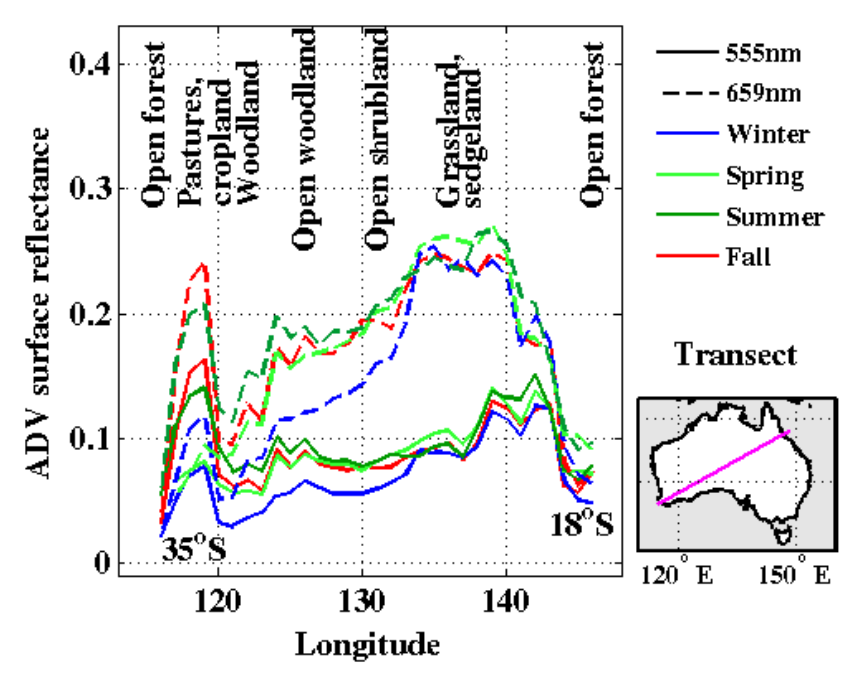

Figure 14. ADV surface reflectance for $555 \mathrm{~nm}$ (solid lines) and for $659 \mathrm{~nm}$ (dashed lines) for winter (June, blue line), spring (September, light-green line), summer (January, green line) and fall (March, red line) along the transect $\left(35^{\circ} \mathrm{S}, 115^{\circ} \mathrm{E}-18^{\circ} \mathrm{S}, 148^{\circ} \mathrm{E}\right)$ over Australia (bottom right image). Vegetation types (http://www. environment.gov.au/node/21580), related to certain areas along the transect, are shown at the top of the figure.

regression equation indicates that the ADV-retrieved surface reflectance is slightly lower than that of MODIS for low surface reflectance (offset $=-0.01$ in January; offset $=-0.02$ in July) and somewhat larger for higher surface reflectance.

\section{Surface reflectance spatial and temporal variation: Australia}

The effect of different vegetation types for different seasons is illustrated with an example of an AATSR transect over Australia $\left(118^{\circ} \mathrm{E}, 35^{\circ} \mathrm{S} ; 148^{\circ} \mathrm{E}, 18^{\circ} \mathrm{S} ; 0.1^{\circ}\right.$ resolution) For this transect, the solar zenith angle changes from $\sim 57^{\circ}$ in the winter to $\sim 33^{\circ}$ in the summer. In spring and fall, the solar zenith angles are $\sim 48^{\circ}$ and $\sim 45^{\circ}$, respectively. Such differences are not significant with respect to their contribution to seasonal variations in the surface reflectance and are therefore neglected in our study. Other directional effects, which are related to vegetation growth and canopy closure, are not taken into account either but could, of course, influence the temporal variability (Knobelspiesse et al., 2008; Breunig et al., 2011).
The spatial and temporal variations in the ADV-retrieved surface reflectance along the transect are shown in Fig. 14, with the different curves color-coded to indicate season and wavelength. Vegetation types are indicated in the figure.

The lowest surface reflectance $(<0.05)$ is observed for the humid mid-latitude forest (southwest and southeast coastal and adjacent inland areas) and also toward the east for subtropical and temperate woodlands and rain forests. Higher surface reflectance (up to $0.15-0.2$ in summer and fall) is observed in southwestern Australia in the dryland agriculture area, as well as on the Nullarbor Plain, which is a livestock grazing area.

Desert or semidesert vegetation is found from the west coast to the interior. This vegetation is composed of tough, spiny grass (such as spinifex and porcupine grass), shrubs such as saltbush, and other drought-resistant plants. As rainfall increases, the vegetation pattern changes. In the summer the surface reflectance in those areas is different from that in other seasons.

The Great Artesian Basin in the northeastern part of South Australia, an area with shrubs and hummock grasses, is characterized by the highest (up to 0.35 at $659 \mathrm{~nm}$ ) surface reflectance. In spring and summer, which are the seasons of increasing fire activity, higher (compared to the rest of the continent) surface reflectance is observed towards the Northern Territory. The land use map (http://www.daff.gov.au/ABARES/aclump/ PublishingImages/Land-use-Aus2005-06-1rg.jpg, 20 July 2014) indicates that this area is partly in native conservation and minimal use, as well as in livestock grazing. This is the area of low precipitation $(<200 \mathrm{~mm}$ per year) and highest temperatures $\left(>45^{\circ} \mathrm{C}\right)$. Towards the northeastern coast, open forest is present and the surface reflectance decreases to values of 0.05 and lower.

Figure 14 also illustrates the seasonal and spectral effects for the different land cover types. Where the difference in reflectance for the two wavelengths is very small near the NE coast (ca. $148^{\circ} \mathrm{E}$ ), it is quite large over the grassland, scrubland and woodland areas to the southeast of the coast. Seasonal differences are small over, for example, the grassland area, and larger toward the southwest.

\section{Concluding remarks}

Land surface reflectance has been retrieved from the AATSR data using an atmospheric correction based on the indepen- 
dent AOD retrieval product from the AATSR dual-view algorithm (ADV), as described in Sect. 3.1. The surface reflectance has been calculated globally with a resolution of $10 \mathrm{~km} \times 10 \mathrm{~km}$ for the AATSR wavelengths at $555 \mathrm{~nm}$ and 659 for the year 2007 .

The validation with the ASRVN network data shows a good agreement with correlation coefficients of 0.8 for $555 \mathrm{~nm}$ and 0.9 for $659 \mathrm{~nm}$ and standard deviation of 0.001 for both wavelengths. The absolute error for each of the land types and for all types together is about 0.02 for both wavelengths. This value meets the climate modeling requirements indicated by Henderson-Sellers and Wilson (1983) and Sellers (1993).

The spatial variation has been evaluated by comparison with MODIS data. RTLS BRF model parameters have been used to compute the reflectance provided by ASRVN and MODIS to the AATSR Sun-satellite viewing geometry. Pixel-by-pixel comparison with MODIS surface reflectance shows good agreement. In January the difference between the ADV and MODIS surface reflectance at $555 \mathrm{~nm}$ is in the range of \pm 0.05 for $97 \%$ of the pixels and in the range of \pm 0.025 for $86 \%$ of the pixels. In July, the differences are similar. For $659 \mathrm{~nm}$ the agreement is slightly lower (89 and $79 \%$, respectively). However, for low surface reflectance the ADV-retrieved reflectance tends to be lower than that from either MODIS or ASRVN, while for higher surface reflectance it tends to be higher. One reason might be that the ADV-retrieved AOD tends to be on the low side for high AODs and thus the atmospheric contribution to the TOA reflection is underestimated, leading to overestimation of the surface reflectance.

The ADV surface reflectance might be potentially used as a surface correction for the land temperature retrieval using AATSR (e.g., Prata et al., 1993). Another possible application of the ADV surface reflectance is the surface correction for the AOD retrieval with MEdium Resolution Imaging Spectrometer (MERIS) onboard the same platform as AATSR (ENVISAT) (von Hoyningen-Huene et al., 2011). The ADV surface reflectance retrieved for 555 and $659 \mathrm{~nm}$ might also be used for narrow to broadband albedo conversion in the visible part of the spectrum (Liang, 2000; Lucht et al., 2008), which is sensitive to the land surface types (Liang et al., 2005; Dozier et al., 2009). The assumptions made by Briegleb et al. (1985) imply that a representative contribution to the broadband TOA radiance comes from the $555-750 \mathrm{~nm}$ spectral interval.

The 17-year data set available from ATSR-2 (1995-2002) and AATSR (2002-2012) provides an excellent opportunity to study long-term surface reflectance variations. The method presented can also be used with the SLSTR (Sea and Land Surface Temperature Radiometer) instrument, which can be considered to be an extended version of AATSR with some extra features, planned to be launched on the Sentinel-3 satellite in 2015 .
Acknowledgements. This work was supported by the Centre of Excellence in Atmospheric Science funded by the Finnish Academy of Science (project no. 272041), the Aerosol-cci project (ESA-ESRIN project AO/1-6207/09/I-LG), and CRAICC (Cryosphere-atmosphere interactions in a changing Arctic climate), part of the Top-level Research Initiative (TRI).

Edited by: O. Torres

\section{References}

Bacour, C. and Bréon, F. M.: Variability of biome reflectance directional signature as seen by POLDER, Remote Sens. Environ., 98, 80-95, 2005.

Breunig, F. M., Galvao, L. S., Formaggio, A. R., and Epiphanio, J. C. N.: Variation of MODIS Reflectance and Vegetation Indices with Viewing Geometry and Soybean Development, An. Acad. Bras. Cienc., 84, 263-274, 2011.

Briegleb, B. P., Minnis, P., Ramanathan, V., and Harrison, E. F.: Comparison of Regional Clear-Sky Albedos Inferred from Satellite Observations and Model Computations, J. Clim. Appl. Meteorol., 25, 214-226, 1985.

Chandrasekhar, S : Radiative Transfer, Dover Publications Inc., p. 393, 1960.

Coddington, O., Pilewskie, P., Schmidt, S., McBride, P. J., and Vukicevic, T.: Characterizing a New Surface-Based Shortwave Cloud Retrieval Technique, Based on Transmitted Radiance for Soil and Vegetated Surface Types, Atmosphere, 4, 48-71, doi:10.3390/atmos4010048, 2013.

Curier, L., de Leeuw, G.,. Kolmonen, P., Sundström, A. -M., Sogacheva, L., and Bennouna,Y.: Aerosol retrieval over land using the ATSR dual-view algorithm, in: Satellite Aerosol Remote Sensing Over Land, edited by: Kokhanovsky, A. A. and de Leeuw, G., Springer-Praxis (Berlin), p. 388, 2009.

de Leeuw, G., Holzer-Popp, T., Bevan, S., Davies, W., Descloitres, J., Grainger, R. G., Griesfeller, J., Heckel, A., Kinne, S., Klüser, L., Kolmonen, P., Litvinov, P., Martynenko, D., North, P. J. R., Ovigneur, B., Pascal, N., Poulsen, C., Ramon, D., Schulz, M., Siddans, R., Sogacheva, L., Tanré, D., Thomas, G. E., Virtanen, T. H., von Hoyningen Huene, W., Vountas, M., and Pinnock, S.: Evaluation of seven European aerosol optical depth retrieval algorithms for climate analysis, RSE, doi:10.1016/j.rse.2013.04.023, in press, 2013.

Dozier, J., Green, R. O., Nolin, A. W., and Painter, T. H.: Interpretation of snow properties from imaging spectrometry, Remote Sens. Environ., 113, S25-S3, 2009.

Flowerdew, R. J. and Haigh, J. D.: An approximation to improve accuracy in the derivation of surface reflectance from multi-look satellite radiometers, Geophys. Res. Lett., 23, 1693-1696, 1995.

Fricke, C., Ehrlich, A., Jäkel, E., Bohn, B., Wirth, M., and Wendisch, M.: Influence of local surface albedo variability and ice crystal shape on passive remote sensing of thin cirrus, Atmos. Chem. Phys., 14, 1943-1958, doi:10.5194/acp-14-19432014, 2014.

Gao, F., Schaaf, C. B., Strahler, A. H., Roesch, A., Lucht, W., and Dickinson, R.: MODIS bidirectional reflectance distribution function and albedo Climate Modeling Grid products and the 
variability of albedo for major global vegetation types, J. Geophys. Res., 110, D01104, doi:10.1029/2004JD005190, 2005.

Grey, W. M. F. and North, P. R. J.: Aerosol optical depth from dual-view (A)ATSR satellite observations, in: Satellite aerosol remote sensing over land, edited by: Kokhanovsky, A. A. and de Leeuw, G., Praxis Publishing Ltd. Chichester, UK, Springer., p. 388, 2009.

Grey, W. M. F., North, P. R. J., and Los, S. O.: Computationally efficient method for retrieving aerosol optical depth from ATSR2 and (A)ATSR data, Appl. Optics, 45, 2786-2795, 2006a.

Grey, W. M. F., North, P. R. J., Los, S. O., and Mitchell, R. M.: Aerosol optical depth and land surface reflectance from multiangle AATSR measurements: global validation and inter-sensor comparisons, IEEE T. Geosci. Remote Sens., 44, 2184-2197, 2006b.

Guanter, L., Gómez-Chova, L., and Moreno J.: Coupled retrieval of aerosol optical thickness, columnar water vapor and surface reflectance maps from ENVISAT/MERIS data over land, Remote Sens. Environ., 112, 2898-2913, 2008.

Hahmann, A. N. and Dickinson, R. E.: A fine-mesh land approach for general circulation models and its impact on regional climate, J. Climate, 14, 1634-1646, 2001.

Hautecoeur, O. and Roujean, J.-L.: Validation of POLDER surface BRDF and albedo products based on a review of other satellites, ground and climate databases, Geoscience and Remote Sensing Symposium IGARSS 2007, IEEE International, 2844-2847, doi:10.1109/IGARSS.2007.4423436, 2007.

Henderson-Sellers, A. and Wilson, M. F.: Surface albedo for climate modeling, Rev. Geophys., 21, 1743-1778, 1983.

Holben, B. N., Eck, T. F., Slutsker, I., Tanré, D., Buis, J. P., Setzer, A., Vermote, E, Reagan, J .A., Kaufman, Y. J., Nakajima, T., Lavenu, F., Jankowiak, I., and Smirnov, A.: AERONET- A federated instrument network and data archive for aerosol characterization, Remote Sens. Environ., 66, 1-16, 1998.

Holzer-Popp, T., de Leeuw, G., Griesfeller, J., Martynenko, D., Klüser, L., Bevan, S., Davies, W., Ducos, F., Deuzé, J. L., Graigner, R. G., Heckel, A., von Hoyningen-Hüne, W., Kolmonen, P., Litvinov, P., North, P., Poulsen, C. A., Ramon, D., Siddans, R., Sogacheva, L., Tanre, D., Thomas, G. E., Vountas, M., Descloitres, J., Griesfeller, J., Kinne, S., Schulz, M., and Pinnock, S.: Aerosol retrieval experiments in the ESA Aerosol_cci project, Atmos. Meas. Tech., 6, 1919-1957, doi:10.5194/amt-61919-2013, 2013.

Jin, Y., Schaaf, C. B., Woodstock, C. E., Gao, F., Li, X., Strahler, A. H., Lucht, W., and Liang, S.: Consistency of MODIS surface bidirectional reflectance distribution function and albedo retrievals: 2. Validation, J. Geophys. Res., 108, 4159, doi:10.1029/2002JD002804, 2003.

Ju, J., Roy, D., Shuai, Y., and Schaaf, C.: Development of an approach for generation of temporally complete daily nadir MODIS reflectance time series, Remote Sens. Environ., 114, 120, doi:10.1016/j.rse.2009.05.022, 2010.

Koelemeijer, R. B. A., Stammes, P., Hovenier, J. W., and de Haan, J. F.: A fast method for retrieval of cloud parameters using oxygen A-band measuremtens from the Global Ozone Monitoring Experiment, J. Geophys. Res., 106, 3475-3490, doi:10.1029/2000JD900657, 2001.

Knobelspiesse, K. D., Cairns, B., Schmid, B., Román, M. O., and Schaaf, C. B.: Surface BRDF estimation from an aircraft compared to MODIS and ground estimates at the Southern Great Plains site, J. Geophys. Res., 113, D20105, doi:10.1029/2008JD010062, 2008.

Kokhanovsky, A. A. and de Leeuw, G.: Satellite Aerosol Remote Sensing Over Land, Springer, 388 pp., 2009.

Kolmonen, P., Sundström, A.-M., Sogacheva, L., Rodriguez, E., Virtanen, T., and de Leeuw, G.: Uncertainty characterization of AOD for the AATSR dual and single view retrieval algorithms, Atmos. Meas. Tech. Discuss., 6, 4039-4075, doi:10.5194/amtd6-4039-2013, 2013.

Lee, T. Y. and Kaufman, Y. J.: Non-Lambertian effects on remote sensing of surface reflectance and vegetation index, IEEE $\mathrm{T}$. Geosci. Remote, 24, 699-708, 1986.

Leroy, M., Deuzé, J. L., Bréon, F. M., Hautecoeur, O., Herman, M., Buriez, J. C., Tanre, D., Bouffies, S., Chazette, P., and Roujean, J. L.: Retrieval of atmospheric properties and surface bidirectional reflectances over the land from POLDER, J. Geophys. Res., 102, 17023-17037, 1997.

$\mathrm{Li}, \mathrm{Z}$.: On the angular correction of satellite radiation measurements: The performance of ERBE angular dependence model in the Arctic, Theor. Appl. Climatol., 54, 235-248, 1996.

Liang, S.: Narrowband to broadband conversions of land surface albedo: I Algorithms, Remote Sens. Environ., 76, 213-238, 2000.

Liang, S., Yu, Y., and Defelice, T. P.: VIIRS narrowband to broadband land surface albedo conversion: formula and validation, Int. J. Remote Sens., 26, 1019-1025, 2005.

Liu, J., Schaaf, C., Strahler, A., Jiao, Z., Shuai, Y., Zhang, Q., Roman, M., Augustine, J. A., and Dutton, E. G.: Validation of Moderate Resolution Imaging Spectroradiometer (MODIS) albedo retrieval algorithm: Dependence of albedo on solar zenith angle, J. Geophys. Res., 114, D01106, doi:10.1029/2008JD009969, 2009.

Lucht, W., Schaaf, C. B., and Strahler, A. H.: An algorithm for the retrieval of albedo from space using semiempirical BRDF models, IEEE T. Geosci. Remote, 38, 977-998, 2000.

Lucht, W., Hyman, A., Strahler, A., Barnsley, M., Hobson, P., and Muller, J.: A comparison of satellite-derived spectral albedos to ground-based broadband albedo measurements modeled to satellite spatial scale for a semidesert landscape, Remote Sens. Environ., 74, 85-98, 2008.

Lyapustin, A. and Knyazikhin, Y.: Green's function method for the radiative transfer problem. I. Homogeneous non-Lambertian surface, Appl. Optics, 40, 3495-3501, 2001.

Lyapustin, A., Wang, Y., Martonchik, J., Privette, J. L., Holben, B., Slutsker, I., Sinyuk, A., and Smirnov, A.: Local analysis of MISR surface BRF and albedo over GSFC and Mongu AERONET sites, IEEE T. Geosci. Remote, 44(7), 1707-1718, 2006.

Lyapustin, A., Wang, Y., Kahn, R., Xiong, J., Ignatov, A., Wolfe, R., Wu, A., Holben, B., and Bruegge, C.: Analysis of MODIS-MISR calibration differences using surface albedo around AERONET sites and cloud reflectance, Remote Sens. Environ., 107, 12-21, 2007.

Manninen, T., Riihelä, A., and de Leeuw, G.: Atmospheric effect on the ground-based measurements of broadband surface albedo, Atmos. Meas. Tech., 5, 2675-2688, doi:10.5194/amt-5-26752012, 2012.

Martonchik, J. V., Diner, D. J., Pinty, B., Verstraete, M. M., Myneni, R. B., Knyazikhin, Y., and Gordon, H. R.: Determination of land 
and ocean reflective, radiative, and biophysical properties using multiangle imaging, IEEE T. Geosci. Remote, 36, 1266-1281, 1998.

National Research Council. Climate Data Records from Environmental Satellites: Interim Report, Washington, DC, The National Academies Press, 2004.

North, P., Briggs, S., Plummer, S., and Settle, J.: Retrieval of land surface bidirectional reflectance and aerosol opacity from ATSR2 multiangle imagery, IEEE T. Geosci. Remote, 37, 526-537, doi:10.1109/36.739106, 1999.

Prata, A. J.: Land surface temperatures derived from the AVHRR and ATSR, 1, Theory, J. Geophys. Res., 98, 16689-16702, 1993.

Ramon, S. B.: Development and evaluation of a MODIS vegetation index compositing algorithm for long-term climate studies. ProQuest Dissertations and Theses; Thesis (Ph.D.) - The University of Arizona, Publication Number: AAT 3487846; ISBN: 9781267075161; Source: Dissertation Abstracts International, 73-04, B, 178, 2011.

Rechid, D., Raddatz, T. J., and Jacob, D.: Parameterization of snowfree land surface albedo as a function of vegetation phenology based on MODIS data and applied in climate modeling, Theor. Appl. Climatol., 95, 245-255, 2009.

Rivkin, A. S., Volquardsen, E. L., and Clark, B. E.: The surface composition of Ceres: Discovery of carbonates and iron-rich clays, Icarus, 185, 563-567, 2006.

Robles González, C.: Retrieval of aerosol properties using ATSR2 observations and their interpretation, $\mathrm{PhD}$ thesis, Universiteit Utrecht, 2003.

Robles González, C., Veefkind, J. P., and de Leeuw, G.: Mean aerosol optical depth over Europe in August 1997 derived from ATSR-2 data, Geophys. Res. Lett., 27, 955-959, 2000.

Robles González, C., Schaap, M., de Leeuw, G., Builtjes, P. J. H., and van Loon, M.: Spatial variation of aerosol properties over Europe derived from satellite observations and comparison with model calculations, Atmos. Chem. Phys., 3, 521-533, doi:10.5194/acp-3-521-2003, 2003.

Román, M. O., Schaaf, C. B., Woodcock, C. E., Strahler, A. H., Yang, X., Braswell, R. H., Curtis, P., Davis, K. J., Dragoni, D., Goulden, M. L., Gu, L., Hollinger, D. Y., Kolb, T. E., Meyer, T. P., Munger, J. W., Privette, J. L., Richardson, A. D., Wilson, T. B., and Wofsy, S. C.: The MODIS (Collection V005) BRDF/albedo product: Assessment of spatial representativeness over forested landscapes, Remote Sens. Environ., 113, 2476-2498, 2009.

Román, M. O., Gatebe, C. K., Shuai, Y., Wang, Z., Gao, F., Masek, J. G., He, T., Liang, S., and Schaaf, C. B.: Use of In Situ and Airborne Multiangle Data to Assess MODIS- and Landsat-Based Estimates of Directional Reflectance and Albedo, IEEE T. Geosci. Remote, 51, 1393-1404, doi:10.1109/TGRS.2013.2243457, 2013.

Roujean, J. L., Leroy, M., and Deschamps, P. Y.: A bidirectional reflectance model of the earth's surface for the correction of the remote sensing data, J. Geophys. Res., 97, 20455-20468, 1992.

Sailor, J. and Fan, H.: Modeling the diurnal variability of effective albedo for cities, Atmos. Environ., 36, 712-725, 2002.

Sayer, A. M., Thomas, G. E., and Grainger, R. G.: A sea surface reflectance model for (A)ATSR, and application to aerosol retrievals, Atmos. Meas. Tech., 3, 813-838, doi:10.5194/amt-3813-2010, 2010.
Sayer, A. M., Thomas, G. E., Grainger, R. G., Carboni, E., Poulson, C., and Siddans, R.: Use of MODIS-derived surface reflectance data in the ORAC-(A)ATSR aerosol retrieval algorithm: Impact of differences between sensor spectral response functions, Remote Sens. Environ., 116, 177-188, doi:10.1016/j.rse.2011.02.029, 2012.

Schaaf, C. B., Gao, F., Strahler, A. H., Lucht, W., Li, X., Tsang, T., Strugnell, N. C., Zhang, X., Jin, Y., Muller, J.-P., Lewis, P., Barnsley, M., Hobson, P., Disney, M., Roberts, G., Dunderdale, M., Doll, C., d'Entremont, R., Hu, B., Liang, S., Privette, J. L., and Roy, D. P.: First Operational BRDF, Albedo and Nadir Reflectance Products from MODIS, Remote Sens. Environ., 83, 135-148, 2002.

Schaaf, C. L., Martonchik, J., Pinty, B., Govaerts, Y., Gao, F., Lattanzio, A., Liu, J., Strahler, A. H., and Taberner, M.: Retrieval of Surface Albedo from Satellite Sensors, in: Advances in Land Remote Sensing: System, Modeling, Inversion and Application, edited by: Liang, S., Springer, ISBN 978-1-4020-6449-4, 219243, 2008.

Schaaf, C. L. B., Liu, J., Gao F., and Strahler, A. H.: MODIS Albedo and Reflectance Anisotropy Products from Aqua and Terra, in: Land Remote Sensing and Global Environmental Change: NASA's Earch Observing System and the Science of ASTER and MODIS, Remote Sensing and Digital Image Processing Series, Vol. 11, edited by: Ramachandran, B., Justice, C., and Abrams, M., Springer-Verlag, 873 pp., 2011.

Schaepman-Strub, G., Schaepman, M. E., Painter, T. H., Dangel, S., and Martonchik, J. V.: Reflectance Quantities in Optical Remote Sensing - Definitions and Case Studies, Remote Sens. Environ., 103, 27-42, 2006.

Seidel, F. C., Kokhanovsky, A. A., and Schaepman, M. E.: Fast retrieval of aerosol optical depth and its sensitivity to surface albedo using remote sensing data, Atmos. Res., 116, 22-32, 2012.

Sellers, P. J., Meeson, B. W., Hall, F. G., Asrar, G., Murphy, R. E., Schiffer, R. A., Bretherton, F. P., Dickinson, R. E., Ellingson, R. G., Field, C. B., Huemmrich, K. F., Justice, C. O., Melack, J. M., Rolet, N. T., Schimel, D. S., and Try, P.D.: Remote sensing of the land surface for studies of global change: Models - algorithms experiments, Remote Sens. Environ., 51, 3-26, 1995.

Strahler, A. H. and Muller, J.-P.: MODIS BRDF/Albedo Product: Algorithm Theoretical Basis Document, NASA EOS-MODIS Doc., Version 5.0., 1999.

Sundström, A.-M., Kolmonen, P., Sogacheva, L., and de Leeuw, G.: Aerosol retrievals over China with the AATSR dual view algorithm, Remote Sens. Environ., 116, 189-198, 2012.

Tao, H.: Estimating land surface albedo from satellite data, Ph.D., UNIVERSITY OF MARYLAND, COLLEGE PARK, available at: http://gradworks.umi.com/35/17/3517829.html (last access: 18 July 2014), 2012.

Tasumi, M., Allen, R., and Trezza, R.: At-Surface Reflectance and Albedo from Satellite for Operational Calculation of Land Surface Energy Balance, J. Hydrol. Eng., 13, 51-63, 2008.

Taylor, V. R. and Stowe, L. L.: Reflectance characteristics of uniform Earth and cloud surfaces, J. Geophys. Res., 89, 4987-4996, 1984.

Thomas, G. E., Poulsen, C. A., Sayer, A. M., Marsh, S. H., Dean, S. M., Carboni, E., Siddans, R., Grainger, R. G., and Lawrence, B. N.: The GRAPE aerosol retrieval algorithm, At- 
mos. Meas. Tech., 2, 679-701, doi:10.5194/amt-2-679-2009, 2009.

Turner, J., Parisi, A. V., and Turnbull, D. J.: Reflected solar radiation from horizontal, vertical and inclined surfaces: ultraviolet and visible spectral and broadband behaviour due to solar zenith angle, orientation and surface type, J. Photoch. Photobio. A, 92, 29-37, 2008.

van Ginneken, B., Stavridi, M., and Koenderink, J. J.: Diffuse and Specular Reflectance from Rough Surfaces, Appl. Optics, 37, 130-139, 1998.

Veefkind, J. P. and de Leeuw, G.: A new algorithm to determine the spectral aerosol optical depth from satellite radiometer measurements, J. Aerosol Sci., 29, 1237-1248, 1998.

Veefkind, J. P., de Leeuw, G., and Durkee, P. A.: Retrieval of aerosol optical depth over land using two-angle view satellite radiometry during TARFOX, Geophys. Res. Lett., 25, 3135-3138, 1998.

von Hoyningen-Huene, W., Yoon, J., Vountas, M., Istomina, L. G., Rohen, G., Dinter, T., Kokhanovsky, A. A., and Burrows, J. P.: Retrieval of spectral aerosol optical thickness over land using ocean color sensors MERIS and SeaWiFS, Atmos. Meas. Tech., 4, 151-171, doi:10.5194/amt-4-151-2011, 2011.

Wagner, T., Beirle, S., Deutschmann, T., Grzegorski, M., and Platt, U.: Satellite monitoring of different vegetation types by differential optical absorption spectroscopy (DOAS) in the red spectral range, Atmos. Chem. Phys., 7, 69-79, doi:10.5194/acp7-69-2007, 2007.

Wang, Y., Lyapustin, A. I., Privette, J. L., Morisette, J. T., and Holben, B.: Atmospheric Correction at AERONET Locations: A New Science and Validation Data Set, IEEE T. Geosci. Remote, 47, 2450-2466, 2009.
Wang, Y., Czapla-Myers, J., Lyapustin, A., Thome, K., and Dutton, E. G.: AERONET-based surface reflectance validation network (ASRVN) data evaluation: Case study for railroad valley calibration site, Remote Sens. Environ., 115, 2710-2717, 2011.

Wang, Y. J., Lyapustin, A. I., Privette, J. L., Cook, R. B., SanthanaVannan, S. K., Vermote, E. F., and Schaaf, C. L.: Assessment of biases in MODIS surface reflectance due to Lambertian approximation, Remote Sens. Environ., 114, 2791-2801, 2010.

Wang, Z., Zeng X., and Barlage, M.: Moderate Resolution Imaging Spectroradiometer bidirectional reflectance distribution function-based albedo parameterization for weather and climate models, J. Geophys. Res., 112, D02103, doi:10.1029/2005JD006736, 2007.

Wanner, W., Strahler, A. H., Hu, B., Lewis, P., Muller, J.-P., Li, X., Barker Schaaf, C. L., and Barnsley, M. J.: Global retrieval of bidirectional reflectance and albedo over land from EOS MODIS and MISR data: theory and algorithm, J. Geophys. Res., 102, 17143-17162, 1997.

Zhou, Y., Brunner, D., Spurr, R. J. D., Boersma, K. F., Sneep, M., Popp, C., and Buchmann, B.: Accounting for surface reflectance anisotropy in satellite retrievals of tropospheric $\mathrm{NO}_{2}$, Atmos. Meas. Tech., 3, 1185-1203, doi:10.5194/amt-3-11852010, 2010. 